\title{
Bilingual Education in Spain: An Analysis of L2 Methodological Requirements and Non-Linguistic Disciplines Within Primary Education Legislation
}

\author{
Gema Alcaraz-Mármol* and María Victoria Guadamillas Gómez \\ University of Castilla-La Mancha, Avda. Carlos III, CP 45071, Toledo, Spain
}

Email: gema.alcaraz@uclm.es*, victoria.guadamillas@uclm.es

\section{ARTICLE INFORMATION}

Received: May 03, 2019

Revised: June 24, 2019

Accepted: August 01, 2019

Published Online: September 04, 2019

Keywords:

CLIL, Primary Education, Legislation,

Plurilingualism, Spanish Education

\begin{abstract}
This article analyses the main legislation in Spain regarding Bilingual Education in the stage of Primary Education. Firstly, it divides Spanish regions into monolingual and bilingual. Later, it deals with the main legislation enforced in Primary Education, and carefully analyses three main aspects: teachers' L2 level, teachers' methodological requirements, and the non-linguistic discipline or disciplines included in bilingual programs together with the subjects' language or languages of delivery and assessment. The first aspect, L2, is labelled following the different levels of the European Framework of Languages. As for teaching methodology, information has been classified as "not mentioned", "recommended" or "required". With regards to subjects, there are four different labels: "compulsory", "optional", "not mentioned", and "not specified". A high degree of heterogeneity is observed in two of the three areas analyzed. These differences among regions do not seem to be connected with their monolingual or bilingual nature. Finally yet importantly, it should be assumed that India and Spain are not close realities in some aspects. However, the study described above might help researchers, teachers or educational authorities to reflect upon some issues which are derived from CLIL(Content and Language Integrated Learning) methodology implementation in schools.
\end{abstract}

\section{Introduction}

Many schools not just in Europe but also in other countries have introduced CLIL (Content and Language Integrated Learning) as a teaching approach. CLIL is rooted in the immersion programmes implemented in schools in Canada (Genesee, 1998). Among the reasons to follow it with young learners, Marsh et al. (2001, p. 7) classifies them into five areas: context, content, language, learning and intercultural reasons. Regarding contextual reasons, we can underscore that CLIL prepares learners for globalization and for access to international certifications of various types (e.g. language certificates, European certification in competences, etc.). Furthermore, CLIL has a number of benefits in content acquisition since the concepts in the subject of study are presented from multiple perspectives. Skills for working life are generally included and subject-specific knowledge is accessed in the L2. With respect to language reasons for implementing CLIL with young learners, this approach will lead to the improvement and development of the target-language oral and written skills. In addition, language awareness in both the first and second language will be acquired and confidence in language use will be developed. As for the learning benefits, we should mention that the diverse methods and approaches that CLIL observes will increase language motivation and address individual learning strategies. Last but not the least, CLIL will help to build intercultural understanding and intercultural communication strategies and will also offer the learners settings wherein/to develop tolerant attitudes and a wider cultural knowledge.

The European Commission insists that Member States should opt for educational policies that foster the learning of at least two foreign languages apart from the mother tongue. In 2003, the Committee of the Regions reported an action plan with the objective of promoting language learning and linguistic diversity in the different states. CLIL (Content and Language Integrated Learning) was considered an adequate approach for this purpose and the Commission considered that it has a major contribution to make 
to the Union's language learning goals. It can provide effective opportunities for pupils to use their new language skills now, rather than learn them for later use. (European Commission, 2003, p.19).

Later on, by means of the Resolution of the Council of Europe (2008) and discussions held within the context of the Ministerial Conference on Multilingualism that same year, the members agreed to foster multilingualism in order to contribute to economic growth, personal and cultural enrichment and social integration and cohesion. In the same vein, the European institutions invited Member States and regional government to develop policies that facilitate early language learning considering bilingual education and, particularly, Content and Language Integrated Learning (CLIL) as effective means for improving these aspects.

Bilingual programs in Spain dates back to the agreements established between the Ministry of Education and the British Council in 2006. However, these former innovative educational practices have grown and expanded quickly among state schools in the last 12 years. According to the Decree 126/2014 developed after the current Law of Education 08/2013, the regional authorities are allowed to determine the discipline taught in the foreign language in light of the previous legislation. Furthermore, the regional government has the power to legislate over the foreign language level that teachers are required to have in order to take part in bilingual programs. Therefore, Spain is a country in which linguistic and cultural diversity has a significant impact on education and language policies, and we find seventeen regions (eleven monolingual and six of them bilingual) with diverse models of bilingualism or multilingualism. Apart from the state laws, nuances and specificities are observed in each region that are materialised in autonomous legislative documents. This fact requires a close examination of teachers' L2 and methodological training requirements, together with a detailed analysis of the various subjects taught in bilingual programs according to the education legislation in each territory. This fact is the main basis and motivation for this study.

\section{Theoretical Framework}

Current research has mainly focused on describing the lexical benefits and studying the methodological issues regarding CLIL implementation in Primary and Secondary Education (Banegas 2016). Moreover, some scholars have paid particular attention to the communicative skills in the L1 and L2 that are involved and developed through this approach or other specific linguistic areas that are enhanced, thanks to the correct methodological implementation of CLIL. A recent study of Ruíz de Zarobe and Iragi (2018) focuses on how the CLIL approach has an effect on L2 reading competence over time, and Nieto (2017) paid special attention to the contribution of CLIL to reading competence in the students' mother tongue. More specifically, Gallardo-Del Puerto, GarciaLecumberri, and Gómez-Lacabex (2009) focused on the effectiveness of CLIL in the pronunciation of the foreign language.

Nikula et al. (2016), Llinares (2015), and DaltonPuffer et al. (2014) have addressed the issue of the integration of content and language in bilingual classroom settings, and Llinares (2015) considered it to be of high importance that teachers in CLIL contexts become aware of "the characteristics of different genres within their academic disciplines and the lexicogrammatical resources required to participate in those genres" (p. 58). In this regard, Lorenzo (2017) explored how this process of integration occurs in the area of History in Secondary Education. By means of students' narratives, the author empirically proved the benefits of the program for both L2 and curriculum development.

Pérez-Cañado (2018) also referred to CLIL and its effects on foreign language achievement. The author reported on the language attainment observed in foreign language learners in Primary and Secondary Education through a longitudinal study conducted in 53 public, private and charter schools in three traditional monolingual regions in Spain. She concluded that it is "CLIL -and not any other co-variate - which is responsible for the linguistic competence differential, so its implementation would undoubtedly be recommendable" (p. 68).

Motivation and its relationship with CLIL has also been the topic of numerous studies. Lasagabaster and López-Beloqui (2015) focused on students' perceptions ofCLIL in the context of Primary Education and closely examined the motivational component in different areas: intrinsic, extrinsic, instrumental and integrative. Furthermore, the study conducted by Lasagabaster and Doiz (2016) attached importance to group work 
and active participation in CLIL and concluded that students' perception of their improvement in English is higher in CLIL contexts than in English as Foreign Language (EFL) settings.

Regarding in-service CLIL teachers' preparation, Durán, Beltrán, and Martínez (2016) focused on the novice and expert teachers' views of Primary and Secondary Education CLIL training and school resources in Spain, and suggested "expert CLIL teachers prioritize methodological competencies and the ability to integrate language and content over subject knowledge and language proficiency" (p. 738). Furthermore, the authors observed how expert teachers acknowledged the lack of suitable material for CLIL teaching, valued cooperation and innovation in CLIL and were more aware of the benefits of bilingual programs. In the same vein, Pérez-Cañado (2017) conducted an investigation in some monolingual regions in Spain (Andalucía, Extremadura, and the Canary Islands), and reported on the main training needs of teachers, students, and parents "in order to successfully implement bilingual education” (p. 129).

Some recent studies have dealt with the bilingual legislation in Spain. For instance, the case of Moliner (2014), who analysed how CLIL was represented in the education law of four Spanish regions: Castilla y León, Extremadura, La Rioja and Galicia. She designed a questionnaire to feature the characteristics of CLIL teachers. Results showed the requirements established in the law were not enough and teachers needed more methodological and foreign language training. What is more, significant differences between CLIL legislation were found among the four regions. Another study by Lozano and Chacón (2017) compared teachers' perceptions on CLIL and language policy in Cantabria. The outcomes of this research showed that language policy in Cantabria was not congruent with CLIL teachers' opinions and requirements.
Nevertheless, a study that closely examines the legislative documents in monolingual and bilingual regions in Spain is still a necessity in order to know the real needs for teacher training in the different regions in Spain. Furthermore, the numerous official documents published by the regional documents have called for the need to address which language (i.e. only L2 or in combination with L1) teachers in each region should use when giving instructionsor assessing students in the CLIL classes as significant differences might be observed.

\section{Objectives of The Study}

This article tries to identify key aspects about teachers' L2 language level and methodological requirements to work in bilingual programs in Primary School in the different regions of Spain.

By means of analysing legislation in this country, we seek to study: -The level of the L2 language that is required in monolingual and bilingual regions.

- The methodological requirements - in terms of training hours or the achievement of a diploma/certificate, which teachers are expected to have in the different regions in order to teach a content area in bilingual programs in Primary Education.

- The non-linguistic disciplines that are the subject of these programs and other considerations regarding the language or languages of delivery established in legislative documents for each of them.

\section{Materials and Method}

\subsection{Legal Documents}

The regional laws of education in Spain may adopt different formats. We can find decrees, orders, resolutions and instructions. Our analysis focuses on the latest documents that have been passed by the regional bodies of government (see Table 1). They are the following:

Table 1: Primary Bilingual legislation documents

\begin{tabular}{|l|l|}
\hline Andalusia & $\begin{array}{l}\text { Joint instructions of 20 May 2015 from the Directorate General for } \\
\text { Educational Innovation and Teacher Training and the Directorate } \\
\text { General for Initial Vocational Training and Lifelong Learning } \\
\text { on the organisation and operation of bilingual education for the } \\
\text { academic year 2015-2016. } \\
\text { Order of 28 June 2011, regulating bilingual education in schools in } \\
\text { the Autonomous Community of Andalusia. }\end{array}$ \\
\hline
\end{tabular}




\begin{tabular}{|c|c|}
\hline Aragon & $\begin{array}{l}\text { Order of March 10, 2014, of the Regional Minister of Education, } \\
\text { University, Culture and Sport, modifying the Order of February } \\
\text { 14, 2013, regulating the Comprehensive Program of Bilingualism } \\
\text { in Foreign Languages in Aragon (PIBLEA) from the 2013-14 } \\
\text { academic year onwards. } \\
\text { Order of August 22, 2013, of the Regional Minister of Education, } \\
\text { University, Culture and Sport, establishing the degrees and } \\
\text { certifications that, with reference to the levels established by the } \\
\text { Common European Framework of Reference for Languages, } \\
\text { certify language knowledge in the field of the competences of the } \\
\text { Department of Education, University, Culture and Sport of the } \\
\text { Government of Aragon. }\end{array}$ \\
\hline Asturias & $\begin{array}{l}\text { Resolution of } 4 \text { June 2015, of the Regional Ministry of Education, } \\
\text { Culture and Sport, which regulates the Bilingual Programme in } \\
\text { non-university educational centres supported by public funds in } \\
\text { Asturias and establishes the procedure for new centres to join the } \\
\text { programme. }\end{array}$ \\
\hline Balears & $\begin{array}{l}\text { Decree } 45 / 2016 \text {, of } 22 \text { July, for the development of communicative } \\
\text { competence in foreign languages in educational centres supported } \\
\text { by public funds in the Balearic Islands. }\end{array}$ \\
\hline Basque Country & $\begin{array}{l}\text { Resolution of } 20 \text { March 2017, of the General Directorate for } \\
\text { Educational Innovation, by which the different subsidies granted } \\
\text { under the Order of } 2 \text { March } 2016 \text { are publicised for the purposes of } \\
\text { general knowledge. Official Bulletin of the Basque Country. }\end{array}$ \\
\hline Canary Islands & $\begin{array}{l}\text { Resolution of } 3 \text { July 2017, of the Directorate General for } \\
\text { Educational Planning, Innovation and Promotion, by which } \\
\text { instructions are given for the development of the plan to promote } \\
\text { foreign languages (PILE) and the modality of integrated learning } \\
\text { of contents and foreign languages (CLIL) in public centres that } \\
\text { provide general education in the Autonomous Community of the } \\
\text { Canary Islands for the 2016-2017 academic year. }\end{array}$ \\
\hline Cantabria & $\begin{array}{l}\text { Order of } 18 \text { November 2013, which regulates bilingual education } \\
\text { programmes in schools in the Autonomous Community of } \\
\text { Cantabria. } \\
\text { Resolution of } 23 \text { February } 2015 \text {, which modifies the list of } \\
\text { certifications accrediting the level of linguistic competence in a } \\
\text { foreign language of the teaching staff of Professors and Secondary } \\
\text { Education Teachers, of Teachers of Vocational Training and of } \\
\text { the Infant and Primary Education Teachers in the Autonomous } \\
\text { Community of Cantabria. }\end{array}$ \\
\hline Castilla-León & $\begin{array}{l}\text { Order of January } 4,2006 \text {, regulating the creation of bilingual } \\
\text { sections in centers supported by public funds of the Community of } \\
\text { Castilla-León. }\end{array}$ \\
\hline Castilla-La Mancha & $\begin{array}{l}\text { Decree } 47 / 2017 \text { of } 25 \text { July, which regulates the plan for the } \\
\text { teaching of foreign languages in the Autonomous Community of } \\
\text { Castilla-La Mancha for non-university educational stages }\end{array}$ \\
\hline Catalonia & $\begin{array}{l}\text { Decree } 119 / 2015 \text { of } 23 \text { June on the planning of the teaching of } \\
\text { primary education. }\end{array}$ \\
\hline Extremadura & $\begin{array}{l}\text { Decree 39/2014, of } 18 \text { March, which establishes the specific } \\
\text { requirements for the certification of the linguistic competence } \\
\text { in a foreign language to teach areas, subjects or modules in } \\
\text { bilingual programmes, and regulates the procedure to obtain } \\
\text { the corresponding linguistic qualification in the scope of the } \\
\text { Autonomous Community of Extremadura. }\end{array}$ \\
\hline
\end{tabular}




\begin{tabular}{|c|c|}
\hline & $\begin{array}{l}\text { Order of April 20, } 2017 \text { which regulates the program of Bilingual } \\
\text { Sections in educational centers supported with public funds of } \\
\text { the Autonomous Community of Extremadura and establishes the } \\
\text { procedure for its implementation in the different educational stages. }\end{array}$ \\
\hline Galicia & $\begin{array}{l}\text { Decree } 105 / 2014 \text {, of } 4 \text { September, establishing the primary } \\
\text { education curriculum in the Autonomous Community of Galicia } \\
\text { Decree } 79 / 2010 \text {, of } 20 \text { May, for multilingualism in non-university } \\
\text { education in Galicia. Order of } 21 \text { June 2016, which modifies } \\
\text { the Order of } 18 \text { February } 2011 \text { establishing the procedure for } \\
\text { certification of language competence of teachers to teach non- } \\
\text { linguistic areas, subjects or modules in a foreign language in public } \\
\text { schools. }\end{array}$ \\
\hline La Rioja & $\begin{array}{l}\text { Decree 24/2014, of } 13 \text { June, establishing the primary education } \\
\text { curriculum in the Autonomous Community of La Rioja. } \\
\text { Order } 7 \text { of } 16 \text { May 2017, of the Regional Ministry of Education, } \\
\text { Training and Employment, which regulates publicly funded } \\
\text { bilingual Infant and Primary schools in the Autonomous } \\
\text { Community of La Rioja. }\end{array}$ \\
\hline Madrid & $\begin{array}{l}\text { Order of October 24, 2014, from the Regional Ministry of } \\
\text { Education, Youth and Sport, for the selection of Public Schools } \\
\text { for Infant and Primary Education in the Community of Madrid } \\
\text { to implement bilingual Spanish-English teaching in Primary } \\
\text { Education during the 2015-2016 school year. } \\
\text { Order of December 7, 2010, from the Regional Ministry of } \\
\text { Education, regulating public bilingual schools in Madrid. }\end{array}$ \\
\hline Navarra & $\begin{array}{l}\text { Foral Order of } 30 \text { December 2016, of the Department of } \\
\text { Education, which regulates the basic aspects of learning } \\
\text { programmes in foreign languages in Infant and Primary Education } \\
\text { centres located in the area of Navarra and authorises certain } \\
\text { educational centres to teach them. }\end{array}$ \\
\hline Region of Murcia & $\begin{array}{l}\text { Order of } 3 \text { June 2016, from the Ministry of Education and } \\
\text { Universities, regulating the foreign language teaching system in the } \\
\text { Region of Murcia. }\end{array}$ \\
\hline Valencia & $\begin{array}{l}\text { Decree } 127 / 2012 \text {, of } 3 \text { August, from the Council, which regulates } \\
\text { multilingualism in non-university education in the Valencian } \\
\text { Community. } \\
\text { Order 44, of August 4, 2016, of the Council of Teaching, Research, } \\
\text { Culture and Sport, which modifies Order } 17 / 2013 \text {, of April 15, } \\
\text { of the Council of Teaching, Research, Culture and Sport, which } \\
\text { regulates the qualifications that enable the teaching of Valencian } \\
\text { and foreign languages in non-university education in Valencia. }\end{array}$ \\
\hline
\end{tabular}

\subsection{Data Analysis}

The Spanish regions were classified according to different parameters. First of all, they were divided into monolingual orbilingual. Spain has five official languages. Spanish is the language that is shared by all regions. Nevertheless, some communities also use another co-official language. Thus, in addition to Spanish, in Catalonia and the Balearic Islands, Catalan is spoken. The co-official language of Galicia is
Galician, and in the Basque Country, Euskera. Finally, in the Valencian Community, along with Spanish, Valencian is considered a co-official language.

The rest of the criteria refers to the information contained in the legal documents. The analysis is based on information about the teachers' L2 level, teaching methodology, and school subjects in the bilingual context. Each criterion is labelled as ad hoc, according to its nature. The first criterion, L2, is labelled following the different levels of the European framework of 
languages. As for teaching methodology, information has been classified as 'not mentioned', 'recommended' or 'required'. In the case of the subjects, there are four different labels: 'compulsory', 'optional', 'not mentioned', and 'not specified'. The fourth label is to be distinguished from the third one in the aspect that there is some information about the subjects or it is too vague, and there is not specification of the particular subjects which the document refers to.

\section{Results and Discussion}

The analysis of the legislation in the different autonomous communities of Spain shows a remarkably heterogeneous and diverse panorama in terms of types of documents where information about CLIL is found. Most of the documents analysed are from the last 3 years. Nonetheless, communities such as the Canary Islands or Castilla-La Mancha have updated their regulations (2017 and 2018), whereas others such as Castilla y León have hardly modified their policy on bilingual education in more than 10 years.

The number of regions and the different legislative documents enforced in each of them, as referred to in the previous section, creates the need for a precise analysis. The results allow us to know if significant differences are observed in L2 level, methodological requirements, and the subject depending on the monolingual or bilingual nature of each region. Furthermore, this analysis can conclude the heterogeneous or homogeneous nature of bilingual policies in Spain.

\subsection{L2 Level Requirements}

The general picture shows a B2 level as the minimum requirement for teachers $(88.23 \%)$. In fact, only two communities ask for a higher level. They are Madrid and Navarra, where at least a C1 level is needed. Monolingual and bilingual communities have a very similar profile in this respect. Only one monolingual community, Madrid, and one among the bilingual communities, Navarra, ask for a L2 level higher than B2. This means that only $11.76 \%$ require their teachers at $\mathrm{C} 1$ level.

According to the Common European Framework of Reference (2001), a B2 level involves the ability to 'interact with a degree of fluency and spontaneity that makes regular interaction with native speakers quite possible'. In addition, someone with a B2 level is expected to participate in discussions related to familiar contexts, being able to express their opinion. A C1 level implies a step further, both in interaction and production. The degree of fluency is expected to be higher, and the user is expected to be able to use the language not just for social purposes, but also for professional purposes. Precision in formulation is also a requirement for this level. In terms of production, a $\mathrm{C} 1$ user of a language should be able to describe complex subjects and develop particular points beyond general or familiar topics. The question is whether a teacher with a B2 level in the foreign language is able to teach a school subject, especially when some subjects contain quite specific and scientific jargon and require complex constructions.

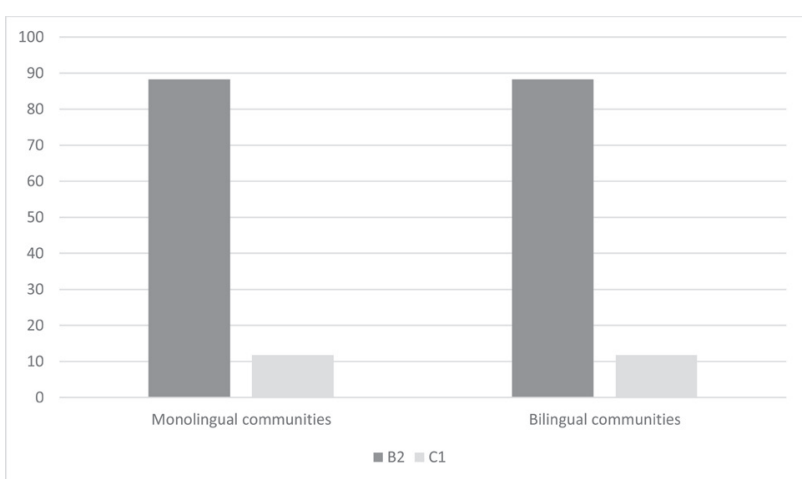

Figure 1: Teachers' L2 level.

\subsection{Methodological Requirements}

Regarding methodological requirements for teachers, the tendency in legislation is not to mentionthat almost $60 \%$ of the regions in Spain do not mention anything about teacher training on CLIL in the educational legal documents consulted (59\%). If mentioned, it is just recommended that teachers have specific training in bilingual teaching. Only a few communities $(18.2 \%)$ of the whole present methodological CLIL training consider it as a requirement, and all of them are monolingual. The bilingual regions do not consider this option in any case except a few recommendations.

CLIL consists of teaching content in an additional language (Paveziet al. 2001). It should be distinguished from content-based instruction, where content is taught in a language different from the students' mother tongue yet has no pedagogical intention in language learning. Marsh (2002) defines CLIL as "any dual-focused educational context in which an additional language, thus not usually the first language 
of the learners involved, is used as a medium in the teaching and learning of non-linguistic content" (p. 15). Thus, in a CLIL context, students are supposed to learn both a foreign language and specific subject content at the same time. That is why it is considered to be a dual-focused educational approachwhere content and language learning should be 'interwoven' (Coyle, Hood and Marsh 2010, p. 1).

As stated by Mehisto, Frigols, and Marsh (2008) and Bertaux et al. (2009) CLIL teachers are expected to have several skills such as the ability to create a supportive target-language environment, promote comprehensible input, and be familiar with the way of integrating language and content. Consequently, it seems reasonable to train teachers in this methodology. Banegas (2012) argues that teachers need specific training in CLIL methodology to overcome the challenges of teaching in a CLIL context.

Mehisto (2008) observed that it was very difficult for teachers to see themselves as CLIL teachers. They used to consider themselves as $\mathrm{L} 2$ or content teachers that used a second language in their lessons. This fact may impinge on teachers' implementation of CLIL. In a study carried out by Butler (2005), results showed that the success of CLIL methodology is closely related to the teachers' lack of skills in the integration of the additional language and content. In fact, Coyle (2007) acknowledges that training opportunities are paramount for teachers. Yet, some studies confirm that the development of policies that promote and support specific practice for CLIL teaching approach is hardly addressed (Ruíz de Zarobe, 2008; Waters, 2009; Lyster \& Ballinger, 2011).

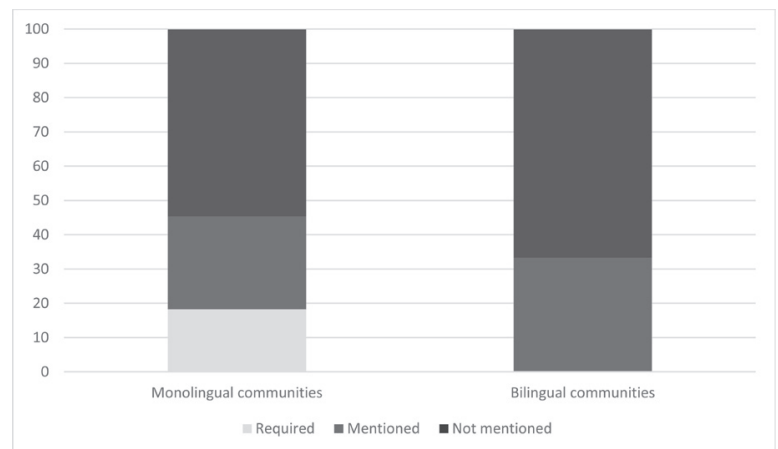

Figure 2: Teachers' methodological requirements.

\subsection{Academic Subjects}

This third aspect is the most complex to analyze given the number of the academic subjects and the diversity in the way they are treated by the law. As explained above, the way subjects are approached in the law has been classified into four categories: 'compulsory', 'optional', 'omission', and 'not specified'. The general tendency here is 'omission', that is to say, legislation tends not to mention anything about the subjects. Nevertheless, there are some communities which seem to address this issue. Social Science and Natural Science are the ones that are compulsory to be taught in English in most regions, and are found to be taught in both monolingual (36.4\%) and bilingual (33.3\%). PE and Art are also compulsory subjects, but only in two bilingual communities, namely Galicia and Navarra.

What is more, making particular subject compulsory is more common in bilingual communities than in monolingual communities. We can find a higher percentage of communities in the bilingual block where several subjects are compulsory. PE and Art appear as optional in some monolingual communities $(27.2 \%)$, whereas the panorama is different in bilingual regions, where optionalityof these subjects is not contemplated in any case. The category of 'not specified' can only be seen in the bilingual block. Two of the six bilingual communities - Catalonia and the Valencian Community - that is $33.3 \%$, show that some subjects will be or can be taught in the foreign language, but they don't specify which ones.

As stated above, the analysis shows that both Social and Natural Science, are the subjects that are compulsory to be taught in the foreign language in many of the regions. This is in line with scholars' recommendations. Ruíz de Zarobe (2012) states that Science is a good supporter for the CLIL environment as it provides many opportunities for students to practice the additional language in various ways. In addition, Hernández and Hernández (2011) highlight the positive role of Social Science as a tool to develop speaking skills. They continue by posing the need of transforming Social Science in the framework to link and combine History and Language, as well as speaking and writing. Together with Science, Arts is usually popular among regional legislation. Burgueño (2013) carried out a study where he asked CLIL teachers about the subjects that they thought were the most adequate for CLIL methodology. Teachers seem to coincide in that Arts is a good option as it provides a creative environment where students feel comfortable and relaxed, so that they are more open to 
using an additional language. What is more, they agree that the content is less dense than other subjects like Mathematics, for instance.

The case of Mathematics is particularly interesting. Most regions opt for setting this subject aside from CLIL teaching. However, in Navarra it is compulsory to include Mathematics as part of the CLIL program. The inclusion of this subject in the CLIL environment is a controversial issue. Scholars such as Escobar (2008) and Pallarés and Petit (2009) consider that Mathematics consitutes a favorable scenario for the development of the CLIL methodology. In fact, Ouazizi (2016) suggests that there may exist "a covert tradeoff between the brain mechanisms involved in learning both Mathematics and languages" (p.By contrast, Burgueño (2013) concludes that this area is too complex to be taught in a foreign language, and this seems to be mirrored in most educational legislation in the various regions.

\section{Final Remarks}

We have explored the main legislation enforced in each region in Spain, and reported some of the similarities and nuances encountered. Monolingual or bilingual classification of regions does not seem to be the reason for diversity in general terms. However, it is necessary to acknowledge that this fact might be behind the diversity of subject or subjects included in programs or the methodological requirements for teachers, since in monolingual communities, the tendency seems to be clearly establishing the non-linguistic areas taught in L2, whereas in bilingual regions, the subjects included in the programs tend to be less defined. As an example, Valencia and Catalonia report that some subjects should be included in bilingual programs without mentioning which ones.

Furthermore, and as it was derived from our analysis, monolingual or bilingual regional classification does not seem to be a factor influencing L2 language level requirements, regardless of the fact that in the first group (monolingual) the emphasis is put on two languages, whereas in the six bilingual communities, policies are designed for two languages apart from Spanish.

Regarding L2 level, both monolingual and bilingual regions required a B2 certification (CEFR). Only in Madrid (monolingual) the C1 level is needed.
Therefore, it seems that 16 out the 17 regions are homogenous in this aspect, with the exception being Navarra whereas it is recommended that teachers have a higher level than B2. This region does not specify a C1 or C2 level, but at least fosters better language skills for teachers. This is the line recently adopted by other regions. For instance, the latest order enforced in Castilla-La Mancha as of February 8/ 2018 establishes that by the year 2022, secondary education teachers will be required a $\mathrm{C} 1$ level. As can be seen, the general tendency is for teachers within bilingual programs to go a step further in their $\mathrm{L} 2$ level and reach a C1 level, but this is not currently a part of the Primary Education legislation as analysed.

By closely examining the methodological requirements, we have observed that CLIL training or bilingual methodological issues are generally not mentioned across the legislation; just less than 20\% of the regions refer to its need. This fact slightly contradicts European policies and recommendations in terms of multilingualism and bilingualism. It is the factual observation that the monolingual regions are the ones that require teachers training in CLIL.

The greatest diversity is found in the disciplines included in bilingual programs. In this regard, Social Sciences and Natural Sciences are usually encountered within bilingual programs in both monolingual and bilingual settings. Nevertheless, a subtle difference is appreciated for Arts and P. E. subjects since according to the legislation they should follow the CLIL approach in some bilingual regions (Galicia and Navarra). As commented above, the case of Mathematics is particularly appealing, as it is forbidden in most of the communities, but is compulsory in Navarra.

In sum, this study offers an overview of the legal landscape of bilingual education in Spain, within the scope of Primary Education. The documents analyzed constitute the most up-to-date legal basis on which the different autonomous communities were governed at the time of the analysis. However, given the importance of the issue in question, it continues to be under debate, with the consequent and presumably expected legal changes in the future.

\section{References}

Banegas, D.L. (2016). Putting CLIL into Practice. Review of Putting CLIL into Practice, by Phil Ball, Keith Kelly 
and John Clegg. International Journal of Bilingual Education and Bilingualism, 21(2), 265-270.

https://doi.org/10.1080/13670050.2016.1146425

Banegas, D.L. (2012). CLIL Teacher Development: Challenges and Experiences. Latin American Journal of Content and Language Integrated Learning, 5(1), 46-56. https://doi.org/10.5294/laclil.2012.5.1.4

Bertaux, P., Coonan, C.M., Frigols-Martín, M.J., \& Mehisto, P. (2009). The CLIL Teacher's Competences Grid. Common Constitution and Language Learning (CCLL) Comenius-Network. Accessed September 15 2018.

http://aprendeenlinea.udea.edu.co/revistas/index.php/ index/oai?verb=ListRecords \& metadataPrefix $=$ oai dc\&set=ikala:EE

Burgueño, J. (2013). Hablan los estudiantes: El bilingüismo en la educación. Revista Padres y Maestros, 350(1), $37-40$.

Butler, Y. G. (2005). Content-based Instruction in EFL Contexts: Considerations for Effective Implementation. Japan Association for Language Teaching Journal, 27(2), 227-245. https://doi.org/10.37546/JALTJJ27.2-5

Council of Europe. (2001). Common European Framework of Reference. Accessed September 152018.

https://www.coe.int/en/web/common-europeanframework-reference-languages/?

European Commission. (2018). Communication from the Commission to the Council, the European Parliament, the Economic and Social Committee and the Committee of the Regions - Promoting Language Learning and Linguistic Diversity: an Action Plan 2004-2006. Accessed September 122018.

https://eur-lex.europa.eu/legal-content/EN/ TXT/?uri=celex\%3A52005DC0596

Coyle, D. (2007). Content and Language Integrated Learning: Towards a Connected Research Agenda for CLIL Pedagogies. The International Journal of Bilingual Education and Bilingualism, 10(5), 543-562.

https://doi.org/10.2167/beb459.0

Coyle, D., Hood, P. \&Marsh, D. (2010). Content and Language Integrated Learning. Cambridge: Cambridge University Press.

Dalton-Puffer, C., Llinares, A., Lorenzo, F. \& Nikula, T. (2014). You Can Stand under my Umbrella: Immersion, CLIL and Bilingual Education. A Response to Cenoz, Genesee and Gorter. 2013. Applied Linguistics, 35(2), 213-218. https://doi.org/10.1093/applin/amu010

Durán-Martínez, R. \& Beltrán-Llavador, F. (2017). Key Issues in Teachers' Assessment of Primary Education
Bilingual Programs in Spain. International Journal of Bilingual Education and Bilingualism, 1(1), 1-14.

Durán-Martínez, R. Beltrán-Llavador, F. \& Martínez-Abad, F. (2016). A Contrastive Analysis between Novice and Expert Teachers' Perceptions of School Bilingual Programmes. Culture and Education, 28(4), 738-770. https://doi.org/10.1080/11356405.2016.1237339

Escobar, C. (2008). Talking English to Learn Science. A CLIL Experience in Barcelona. In. Melinda, D. (Eds.), How We're Going about It. Teachers' Voices on Innovative Approaches to Teaching and Learning Languages (pp. 154-169). Cambridge: Cambridge ScholarPress.

del Puerto, F.G., Lecumberri, M.L.G., \& Lacabex, E.G. (2009). Testing the Effectiveness of Content and Language Integrated Learning in Foreign Language Contexts: The Assessment of English Pronunciation. In. de Zarobe, Y.R., \& Catalán, R.M.J. (Eds.), Content and Language Integrated Learning: Evidence from Research in Europe (pp. 215-234). Bristol, UK: Multilingual Matters.

https://doi.org/10.21832/9781847691675-007

Genesee, F. (1998). A case study of multilingual education in Canada. Beyond bilingualism: Multilingualism and multilingual education, 243-258.

Hernández, L. \& Hernández, C. (2011). La expresion oral y escrita como proceso clave en el aprendizaje de las Ciencias Sociales. Didáctica de las Ciencias Experimentales y Sociales, 25(3), 213-222.

Lasagabaster, D. \& Doiz, A. (2016). CLIL Students' Perceptions of their Language Learning Process: Delving into Self-perceived Improvement and Instructional Preferences. Language Awareness, 25(12), 110-126.

https://doi.org/10.1080/09658416.2015.1122019

Lasagabaster, D. \& Lopez-Beloqui, R. (2015). The Impact of Type of Approach (CLIL versus EFL) and Methodology. Book-Based Versus Project Work on Motivation. Porta Linguarum 23(1), 41-57.

Llinares, A. (2015). Integration in CLIL: A Proposal to Inform Research and Successful Pedagogy. Language, Culture and Curriculum, 28(1), 58-73.

https://doi.org/10.1080/07908318.2014.1000925

Lorenzo, F. (2017). Historical Literacy in Bilingual Settings: Cognitive Academic Language in CLIL History Narratives. Linguistics and Education, 37(1), 32-41. https://doi.org/10.1016/j.linged.2016.11.002

Lyster, R. \& Ballinger, S. (2011). Content-based Language Teaching: Convergent Concerns across Divergent Contexts. Language Teaching Research, 15(3), 279-288. https://doi.org/10.1177/1362168811401150 
Marsh, D. (2002). CLIL-EMILE. The European dimension: Actions, Trends and Foresight Potential. Brussels: European Comission.

Marsh, D., Maljers, A., \& Hartiala, A.K. (2001). Profiling European CLIL Classrooms. Jyväskylä, Finland: Centre for Applied Language Studies.

Martínez Lozano, L. \& Chacon Beltran, R. (2017). La legislación de los programas bilingües en Educación Infantil y Primaria desde la perspectiva docente. Revista Electrónica de Lingüistica Aplicada, 16(1), 3-22.

Mehisto, P. (2008). CLIL Counterweights: Recognizing and Decreasing Disjuncture in CLIL. International CLIL Research Journal, 1(1), 93-119.

Mehisto, P., Frigols-Martín, M. J. \&Marsh, D. (2008). Uncovering CLIL. Oxford: Macmillan.

Moliner Bernabé, M. (2014). La influencia de la legislación de cada una de las Comunidades Autónomas en el desempeño del rol del profesor de metodología AICLE. $\mathrm{PhD}$ diss., Universidad Pontificia de Salamanca.

Nieto, E. (2017). How does CLIL Affect the Acquisition of Reading Comprehension in the Mother Tongue? A Comparative Study in Secondary Education. Investigaciones Sobre Lectura, 8(1), 7-26. https://doi.org/10.37132/isl.v0i8.214

Nikula, T., Dafouz, E., Moore, P. \& Smit, U. (2016). Conceptualising Integration in CLIL and Multilingual Education. Bristol, UK: Multilingual Matters. https://doi.org/10.21832/9781783096145

Ouazizi, K. (2016). The Effects of CLIL Education on the Subject Matter (Mathematics) and the Target Language (English). Latin American CLIL Journal, 9(1), 110-137. https://doi.org/10.5294/laclil.2016.9.1.5
Pallares, O. \& Petit, C. (2009). Matemáticas e ingles. Un tandem con objetivos comunes. Cuadernos de Pedagogía, 395(2), 66-69.

Pavezi, M., Bertocchi, D., Hofmannová, M. \& Kazianka, M. (2001). CLIL Guidelines for Teachers. TIE CLIL.

Perez-Cañado, M. L. (2017). CLIL Teacher Education: Where do We Stand and Where do We Need to Go? In Bilingual Education: Educational Trends and Key, edited by Elena Gómez Parra and Richard Johnstone, 129-145. Madrid: Ministry of Education, Culture and Sport.

Perez Cańado, M. L. (2018). CLIL and Educational Level: A Longitudinal Study on the Impact of CLIL on Language Outcomes. Porta Linguarum, 29(2), 51-70.

Ruíz de Zarobe, Y. (2008). CLIL and Foreign Language Learning. A longitudinal Study in the Basque Country. International CLIL Research Journal, 1(1), 60-73.

Ruíz de Zarobe, Y. (2012). Del aprendizaje tradicional al enfoque integrado de lenguas en estadios adquisitivos avanzados. Lenguaje y Textos, 35(2), 95-100.

Ruíz de Zarobe, Y. \& ZenotzIragi, V. (2018). Learning Strategies in CLIL Classrooms: How does Strategy Instruction Affect Reading Competence over Time? International Journal of Bilingual Education and Bilingualism, 21(3), 319-331. https://doi.org/10.1080/13670050.2017.1391745

Waters, A. (2009). Managing Innovation in English Language Education. Language Teaching, 42(4), 421458.

https://doi.org/10.1017/S026144480999005X 


\section{旬 \\ CHITKARA}

\section{Issues and Ideas in Education}

Chitkara University, Saraswati Kendra, SCO 160-161, Sector 9-C, Chandigarh, 160009, India

Volume 7, Issue 2

September 2019

ISSN 2320-7655

Copyright: [C 2019 Gema Alcaraz-Mármol and María Victoria Guadamillas Gómez] This is an Open Access article published in Issues and Ideas in Education (Issues Ideas Educ.) by Chitkara University Publications. It is published with a Creative Commons Attribution- CC-BY 4.0 International License. This license permits unrestricted use, distribution, and reproduction in any medium, provided the original author and source are credited. 